\title{
CD14 and Toll-Like Receptors 2 and 4 Are Required for Fibrillar A $\beta$-Stimulated Microglial Activation
}

\author{
Erin G. Reed-Geaghan, ${ }^{1}$ Julie C. Savage,${ }^{1}$ Amy G. Hise, ${ }^{2}$ and Gary E. Landreth ${ }^{1}$ \\ ${ }^{1}$ Alzheimer Research Laboratory, Department of Neurosciences, School of Medicine, and ${ }^{2}$ Center for Global Health and Diseases, Case Western Reserve \\ University, Cleveland, Ohio 44106
}

Microglia are the brain's tissue macrophages and are found in an activated state surrounding $\beta$-amyloid plaques in the Alzheimer's disease brain. Microglia interact with fibrillar $\beta$-amyloid (fA $\beta$ ) through an ensemble of surface receptors composed of the $\alpha_{6} \beta_{1}$ integrin, CD36, CD47, and the class A scavenger receptor. These receptors act in concert to initiate intracellular signaling cascades and phenotypic activation of these cells. However, it is unclear how engagement of this receptor complex is linked to the induction of an activated microglial phenotype. We report that the response of microglial cells to fibrillar forms of $\mathrm{A} \beta$ requires the participation of Toll-like receptors (TLRs) and the coreceptor CD14. The response of microglia to fA $\beta$ is reliant upon CD14, which act together with TLR4 and TLR2 to bind $\mathrm{fA} \beta$ and to activate intracellular signaling. We find that cells lacking these receptors could not initiate a Src-Vav-Rac signaling cascade leading to reactive oxygen species production and phagocytosis. The fA $\beta$-mediated activation of p38 MAPK also required CD14, TLR4, and TLR2. Inhibition of $\mathrm{p} 38$ abrogated $\mathrm{fA} \beta$-induced reactive oxygen species production and attenuated the induction of phagocytosis. Microglia lacking CD14, TLR4, and TLR2 showed no induction of phosphorylated $\mathrm{I} \kappa \mathrm{B} \alpha$ following fA $\beta$. These data indicate these innate immune receptors function as members of the microglial fA $\beta$ receptor complex and identify the signaling mechanisms whereby they contribute to microglial activation.

\section{Introduction}

Alzheimer's disease $(\mathrm{AD})$ is the most common cause of dementia in the elderly, and is characterized by extensive extracellular deposits of insoluble $\beta$-amyloid $(\mathrm{A} \beta)$ in the brain. The most widely held hypothesis for $\mathrm{AD}$ pathogenesis posits that a chronic imbalance in the production and clearance of $A \beta$ results in a persistent increase in its steady-state levels, ultimately leading to the complex molecular and cellular changes within the brain that typify $\mathrm{AD}$ (Selkoe, 2000). A $\beta$ deposition is accompanied by a robust microglial-mediated inflammatory response within the brain (Akiyama et al., 2000). Microglia surrounding A $\beta$ plaques show an activated phenotype and extend processes that envelop the plaque (Itagaki et al., 1989; Perlmutter et al., 1990; Bornemann et al., 2001).

Microglia are the brain's tissue macrophage and continuously survey their immediate environment (Davalos et al., 2005; Nimmerjahn et al., 2005). Following insult, microglia shift from a surveillance to a reactive mode, engaging their immune effector roles to respond to the injury or pathogens. Myeloid lineage cells use ensembles of cell surface receptors to bind com-

Received July 2, 2009; revised Aug. 18, 2009; accepted Aug. 19, 2009.

This work was supported by National Institutes of Health Grant AG16047 and Neuroscience Training Grant 5 T32 AG0071, the Blanchette Hooker Rockefeller Foundation, and the American Health Assistance Foundation. Erin G. Reed-Geaghan is supported by a predoctoral Ruth L. Kirschstein National Research Service Award (F31NS057867) from the National Institute of Neurological Disorders and Stroke. We thank Dr. Shizuo Akira for generously sharing $\mathrm{TLR2}^{-/-}$and TLR4 ${ }^{-1-}$ mice.

Correspondence should be addressed to Gary E. Landreth, School of Medicine, Case Western Reserve University, 10900 Euclid Avenue, Cleveland, 0H 44106-4928. E-mail: gel2@case.edu.

DOI:10.1523/JNEUROSCI.3158-09.2009

Copyright $\odot 2009$ Society for Neuroscience $\quad$ 0270-6474/09/2911982-11\$15.00/0 plex entities, including fibrillar proteins (Ishibashi et al., 1994; Bornstein, 1995; Wong et al., 1996). Bamberger et al. identified a complex of microglial membrane receptors for fibrillar $\mathrm{A} \beta$ (fA $\beta$ ) consisting of the $\alpha_{6} \beta_{1}$ integrin, CD36, CD47, and the class A scavenger receptor (SRA) (Bamberger et al., 2003). Engagement of this receptor complex activates tyrosine kinase-based signaling cascades (McDonald et al., 1997; Combs et al., 1999; Bamberger et al., 2003) resulting in reactive oxygen species (ROS) production, secretion of cytokines, and phagocytosis (Koenigsknecht and Landreth, 2004; Wilkinson et al., 2006).

Toll-like receptors (TLRs) are expressed on cells of the innate immune system, and act to mobilize a robust immune reaction in response to pathogens (Akira, 2001; Medzhitov, 2001). TLRs function as dimers and often use coreceptors such as CD14 to assist in pathogen recognition. Specifically, CD14 interacts with TLR4- and TLR2-containing dimeric complexes to transduce activation signals in response to bacterial pathogens (Kielian, 2006). Importantly, TLRs have been found to associate with other receptors, such as CD36 and CD47 (Pfeiffer et al., 2001; Triantafilou et al., 2006) to elicit monocyte/macrophage activation (Triantafilou et al., 2004). A number of studies have reported an association between TLRs and $\mathrm{AD}$, but have not defined a mechanistic link for how they participate in the microglial response to fA $\beta$ (Fassbender et al., 2004; Liu et al., 2005; Walter et al., 2007; Jana et al., 2008; Richard et al., 2008; Udan et al., 2008).

We report that microglia cultured from CD14-, TLR4-, or TLR2-null mice were unable to initiate signaling through a SrcVav-Rac signaling cascade necessary for the induction of ROS and of phagocytosis following exposure to fA $\beta$. Furthermore, 
fA $\beta$-induced activation of p38 MAP kinase was abrogated in microglia deficient in CD14, TLR4, or TLR2, preventing subsequent ROS and phagocytosis. Together, these data indicate CD14, TLR4, and TLR2 functionally interact with other members of the microglial fA $\beta$ receptor complex to initiate intracellular signaling cascades resulting in an activated phenotype.

\section{Materials and Methods}

Reagents. $\mathrm{A} \beta_{1-42}$ peptide was purchased from American Peptide Company, dissolved in endotoxin-free sterile water and incubated at $37^{\circ} \mathrm{C}$ for $24 \mathrm{~h}$ to induce fibril formation. The initial concentration reflects that of the monomeric peptides used to generate the fibrils. This preparation has been well described (Burdick et al., 1992; Lorenzo and Yankner, 1994). E. coli K12 lipopolysaccharide (LPS) was purchased from List Biological Laboratories and dissolved in endotoxin-free sterile water at $1 \mathrm{mg} / \mathrm{ml}$. Pam3CSK4 purchased from InvivoGen was dissolved in endotoxin-free sterile water. Phorbol 12-myristate 13-actetate (PMA) was purchased from Sigma and dissolved in ethanol. Immune IgG was prepared from goat anti-rabbit IgG from Sigma and rabbit anti-mouse IgG from Cappel in a 5:1 ratio as described previously (Koenigsknecht and Landreth, 2004). Nitroblue tetrazolium chloride (NBT) was purchased from Roche. FluoSpheres ( $1 \mu \mathrm{m}$ microspheres) were purchased from Invitrogen. The CD14 antibody MY4 was purchased from Beckman Coulter. Function blocking antibodies to TLR4 (HTA-125), TLR2 (T2.5), CD47 (B6H12), and isotype control antibodies $\left(\operatorname{IgG}_{1}, \operatorname{IgG}_{2 \mathrm{a}}, \operatorname{IgG}_{2 \mathrm{~b}}\right)$ were purchased from eBioscience. The CD36 antibody FA6-152 was from Abcam. Antibodies detecting phospho-Src, and phospho-p38, were purchased from Cell Signaling Technology. The anti-phospho-tyrosine antibody 4G10 and Rac antibody were purchased from Upstate Biotechnologies. Antibodies to Phospho-I $\kappa \mathrm{B} \alpha, \mathrm{c}-\mathrm{Src}, \mathrm{Vav}, \mathrm{p} 38$, and actin were purchased from Santa Cruz Biotechnology. The antibody to flotillin was purchased from BD Transduction Laboratories. Polymixin B was purchased from Sigma, and SB203580 from Invivogen.

Cell culture. CD14 ${ }^{-1-}$ and C57BL/6J mice were from Jackson Laboratories, TLR $4^{-1-}$ and TLR2 ${ }^{-1-}$ mice were generated by Shizuo Akira (Osaka University, Osaka, Japan). Primary microglia were cultured from postnatal day $0-3 \mathrm{CD} 14^{-1-}$, TLR $4^{-1-}$, TLR2 ${ }^{-1-}$, or C57BL/6J mice as previously described by us (McDonald et al., 1997). Briefly, pups were decapitated, and meninges and blood vessels were completely removed from the cortices, which were minced and trypsinized with $0.05 \%$ Trypsin-EDTA (Invitrogen) for $20 \mathrm{~min}$ at $37^{\circ} \mathrm{C}$. DMEM/F12 (Invitrogen) containing 10\% heat-inactivated fetal bovine serum (HI-FBS; Atlanta Biologicals) and 1\% penicillin-streptomycin (Invitrogen) was used to stop the digestion. Cells were then triturated and plated on $150 \mathrm{~mm}$ dishes (Corning). Media was changed the following day to fresh DMEM/ F12 with $10 \% \mathrm{HI}-\mathrm{FBS}$ for $14-21 \mathrm{~d}$ at $37^{\circ} \mathrm{C}, 5 \% \mathrm{CO}_{2}$. Microglia were isolated as described by Saura et al. (2003) by shaking the tissue culture plates for $30 \mathrm{~min}$ at room temperature to remove loosely adherent microglia. Astrocytes were next removed by $0.25 \%$ trypsin/HBSS diluted $1: 4$ in serum-free DMEM/F12 for $1 \mathrm{~h}$ at $37^{\circ} \mathrm{C}$. Firmly attached microglia were harvested using $0.25 \%$ trypsin/PBS. Loosely and firmly adherent microglia were combined, and cells were counted and plated for experiments at the appropriate density in DMEM/F12 containing 2\% HI-FBS overnight. Media was changed to serum-free DMEM/F12 overnight before beginning the experiment.

The immortalized human monocyte cell line THP-1 from American Type Culture Collection was maintained in RPMI 1640 (Invitrogen) containing $10 \%$ HI-FBS and gentamycin. The immortalized murine microglial cell line BV2 was maintained in DMEM (Invitrogen) containing 2\% HI-FBS and gentamycin (Blasi et al., 1990).

Cellular adhesion assay. Cellular binding to $\mathrm{fA} \beta$ was performed as previously described (Bamberger et al., 2003). THP-1 monocytes $(5 \times$ $10^{5}$ cells/condition) were incubated at $37^{\circ} \mathrm{C}$ for $30 \mathrm{~min}$ in serum-free RMPI 1640 in the presence or absence of function blocking antibodies to CD14 (MY4, $10 \mu \mathrm{g} / \mathrm{ml}$ ), TLR4 (HTA125, $10 \mu \mathrm{g} / \mathrm{ml}$ ), TLR2 (T2.5, $10 \mu \mathrm{g} / \mathrm{ml}$ ), CD36 (FA6-152, $10 \mu \mathrm{g} / \mathrm{ml})$, CD47 (B6H12, $20 \mu \mathrm{g} / \mathrm{ml}$ ), their isotype controls $\left(\operatorname{IgG}_{1}, \operatorname{IgG}_{2 \mathrm{a}}\right.$, or $\left.\operatorname{IgG}_{2 \mathrm{~b}}\right)$, or polymixin $\mathrm{B}(0.1$ $\mu \mathrm{g} / \mathrm{ml})$. Fibrillar $\mathrm{A} \beta_{1-42}(2 \mu \mathrm{g})$ was applied to a glass slide and allowed to dry. Cells $(20,000)$ were applied to the slide and allowed to adhere for $5 \mathrm{~min}$. Following washing with RPMI, the number of adherent cells was counted in three independent fields on an inverted microscope.

Phagocytosis assay. Measurement of $\mathrm{fA} \beta$-stimulated microglial phagocytosis was performed as previously described (Koenigsknecht and Landreth, 2004). Microglia were plated at a density of 100,000 cells/well of a 24 -well plate. SB203580 $(0.5 \mu \mathrm{M})$ or function blocking antibodies were added to serum-free media for $30 \mathrm{~min}$ at $37^{\circ} \mathrm{C}$. Media was collected, and $\mathrm{fA} \beta_{1-42}(2.5 \mu \mathrm{M})$ was added for $30 \mathrm{~min}$ at $37^{\circ} \mathrm{C}$. Fluorescent microspheres washed in PBS containing $1 \mathrm{mg} / \mathrm{ml}$ BSA were added to the cells for an additional $30 \mathrm{~min}$. Cells were then fixed with $2 \%$ paraformaldehyde, and the three random fields totaling at least 100 cells were counted for the fraction of cells containing microspheres on an inverted microscope.

Reactive oxygen species assay. Measurement of intracellular superoxide radical generation was measured by the formation of a dark blue formazan deposit resulting from superoxide-mediated reduction of NBT (Pick, 1986; McDonald et al., 1997). Briefly, cells were plated at a density of 100,000 cells/well of a 24-well plate. SB203580 (0.5 $\mu \mathrm{M})$ was added to serum-free media for $30 \mathrm{~min}$ at $37^{\circ} \mathrm{C}, 5 \% \mathrm{CO}_{2}$. Media was collected and $\mathrm{fA} \beta_{1-42}(2.5 \mu \mathrm{M})$, LPS $(5 \mu \mathrm{g} / \mathrm{ml})$, Pam3CSK4 $(1 \mu \mathrm{M})$, or PMA (390 nм) was added to the cells for an additional $30 \mathrm{~min}$ at $37^{\circ} \mathrm{C}$ in the presence of $1 \mathrm{mg} / \mathrm{ml} \mathrm{NBT}$. Cells were fixed with $2 \%$ paraformaldehyde at $4^{\circ} \mathrm{C}$ for $30 \mathrm{~min}$. Three random fields totaling at least 100 cells were counted on an inverted microscope and the fraction of ROS-positive cells was determined.

Cell stimulation, immunoprecipitations and Western blots. Cells were plated at $2.5 \times 10^{6}$ cells $/ 60 \mathrm{~mm}$ dish, and stimulated with $\mathrm{fA} \beta_{1-42}(2.5$ $\mu \mathrm{M})$, LPS $(5 \mu \mathrm{g} / \mathrm{ml})$, Pam3CSK4 $(1 \mu \mathrm{M})$, or immune IgG $(250 \mu \mathrm{g} / \mathrm{ml})$ in serum-free DMEM/F12 for 3 or $5 \mathrm{~min}$ at room temperature. Cells were collected and lysed in Triton buffer (1\% Triton X-100, 20 mM Tris, pH 7.5, $100 \mathrm{~mm} \mathrm{NaCl}, 40 \mathrm{~mm} \mathrm{NaF}, 1 \mathrm{~mm}$ EDTA, 1 mm EGTA) containing the protease inhibitors leupeptin $(1 \mu \mathrm{g} / \mathrm{ml})$, aprotinin $(1 \mu \mathrm{g} / \mathrm{ml})$, PMSF $(1$ $\mathrm{mm}$ ), and $\mathrm{Na}_{3} \mathrm{VO}_{4}(1 \mathrm{~mm})$. Lysates were cleared by centrifugation (15 $\left.\min , 4^{\circ} \mathrm{C}, 500 \times \mathrm{g}\right)$. Protein concentration was determined by the BCA method (Pierce). Cellular lysates $(0.5 \mathrm{mg})$ were added to $30 \mu \mathrm{l}$ Protein A agarose beads (Santa Cruz Biotechnology) and $2 \mu \mathrm{g}$ of the anti-Vav antibody per milligram of lysate and rotated at $4^{\circ} \mathrm{C}$ for at least $2 \mathrm{~h}$. Samples were washed three times with Triton buffer, followed by the addition of sample buffer. Immunoprecipitations or aliquots of lysate $(30 \mu \mathrm{g}$ of protein) were boiled for $5 \mathrm{~min}$, loaded onto $9 \%$ SDS-PAGE gels, and transferred to polyvinylidenedifluoride membranes (Millipore). Blots were probed with anti-phosphotyrosine (1:1000), -phospho-Src (1:1000), -phospho-p38 (1:1000), or -phospho-I $\kappa \mathrm{B} \alpha(1: 1000)$ antibodies overnight at $4^{\circ} \mathrm{C}$. The antigens were detected by anti-mouse or anti-rabbit HRP-conjugated secondary antibodies and visualized by enhanced chemiluminescence (Pierce). Blots were stripped and reprobed with antibodies to Vav (1:1000), c-Src (1:200), p38 (1:1000), or actin (1:1000) for evaluation of loading and immunoprecipitation efficiency. Band intensities were quantified using NIH ImageJ software (Bethesda, MD).

Cellular fractionation. The isolation of cytoplasmic and membrane fractions were performed as previously described (Wilkinson et al., 2006). Primary microglia were plated at $2.5 \times 10^{6}$ cells $/ 60 \mathrm{~mm}$ dish. Cells were stimulated with $\mathrm{fA} \beta_{1-42}(2.5 \mu \mathrm{M})$ in serum-free DMEM/F12 for 10 $\mathrm{min}$ at room temperature, collected and lysed in Relaxation buffer (100 mм KCl, 3 mм NaCl, 3.5 mм $\mathrm{MgCl}_{2}, 1.25 \mathrm{~mm}$ EGTA, and $10 \mathrm{~mm}$ PIPES, $\mathrm{pH}$ 7.3), and incubated on ice for $15 \mathrm{~min}$. Following a $10 \mathrm{~s}$ sonication, lysates were cleared by centrifugation at $500 \times g, 4^{\circ} \mathrm{C}$ for $5 \mathrm{~min}$. The supernatants were centrifuged for an hour at $110,000 \times \mathrm{g}, 4^{\circ} \mathrm{C}$ using a Beckman Coulter SW50.1 rotor. The supernatant (cytosolic fraction) was collected, and the resulting membrane pellet then resuspended in Relaxation buffer. The samples (30 $\mu \mathrm{g}$ of protein) were loaded onto a $12 \%$ SDS-PAGE resolving gel and the resulting blots were probed with an anti-Rac antibody (1:1000) and an anti-flotillin antibody (1:1000) to determine the relative amount of membrane-associated Rac. Band intensities were quantified using NIH ImageJ software.

Statistical analysis. All replications of each experiment were pooled to generate graphical representations. GraphPad Prism 3.02 software was 

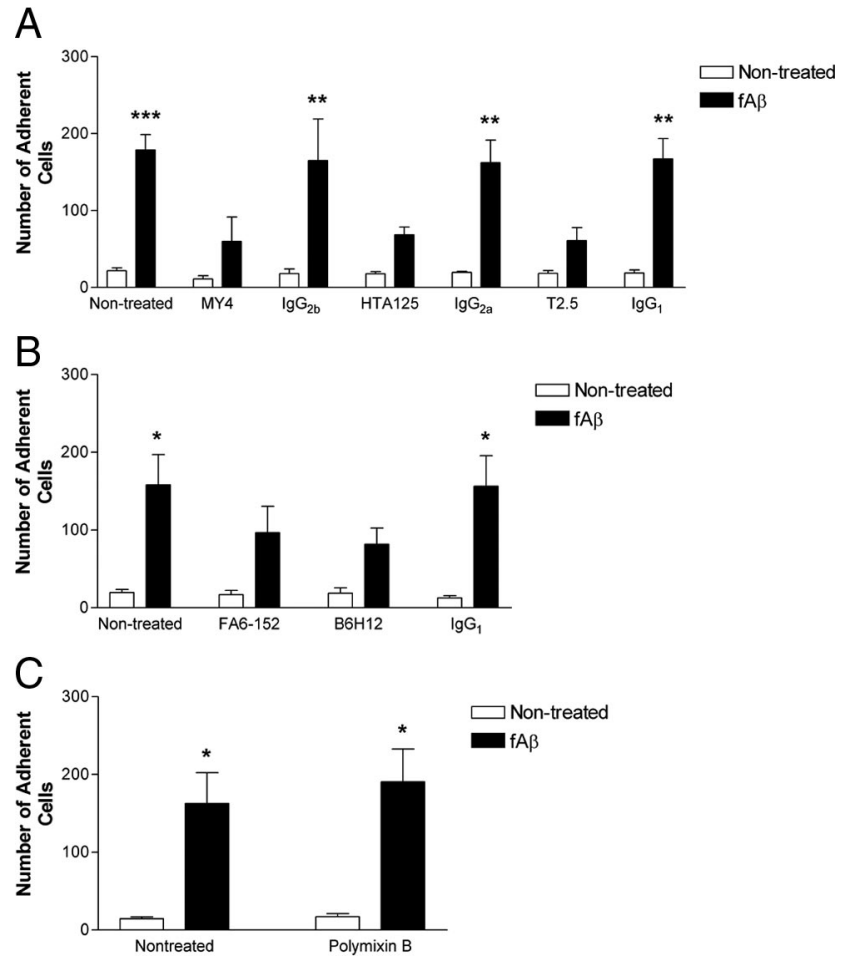

Figure 1. CD14, TLR4, and TLR2 mediate the recognition and binding of $A A \beta$. $A, B$, THP-1 monocytes were incubated in the presence or absence of function blocking antibodies to CD14 (MY4, A), TLR4 (HTA125, A), TLR2 (T2.5, A), CD36 (FA6-152, B), CD47 (B6H12, B), or their isotype controls $\left(\lg _{2}, \operatorname{lgG}_{2 a}, \lg _{1}\right)$. Cells were then added to $\mathrm{f} A \beta$ bound to a glass slide and the number of adherent cells was determined. C, THP-1 monocytes were incubated in the presence or absence of $0.1 \mu \mathrm{g} / \mathrm{ml}$ polymixin $B$. Cells were then added to $\mathrm{f} A \beta$ bound to a glass slide and the number of adherent cells was determined. The data shown are the mean \pm SEM of three independent experiments. ${ }^{*} p<0.05,{ }^{* *} p<0.01,{ }^{* * *} p<0.001$ compared with Non-treated.

used to calculate mean values \pm SEM, and statistical differences were determined using a one-way ANOVA with a Tukey posttest to determine $p$ values.

\section{Results}

\section{CD14, TLR4, and TLR2 mediate binding of fA $\beta$}

We investigated the participation of TLRs and the coreceptor CD14 to stimulate microglial activation by testing whether CD14 physically interacted with $\mathrm{fA} \beta$ and mediated the binding of the fibrils to the cell. THP-1 monocytes were used as they are normally nonadherent and provide a sensitive system for assessing $\mathrm{fA} \beta$-binding. Monocytes avidly bind to $\mathrm{fA} \beta$; however, pretreatment of THP-1 monocytes with function blocking antibodies to CD14 (MY4), TLR4 (HTA125), or TLR2 (T2.5) dramatically inhibited the binding of monocytes to $\mathrm{fA} \beta$ (Fig. $1 A$ ). Isotype control antibodies did not affect binding to $\mathrm{fA} \beta$, demonstrating the specificity of this effect. The association of these cells with fA $\beta$ was also blocked by function blocking antibodies to CD36 (FA6152 ) and CD47 (B6H12) (Fig. 1B), receptors that have been previously reported to be required for $\mathrm{fA} \beta$ binding (Bamberger et al., 2003). Polymixin B, which binds the lipid A component of LPS to neutralize endotoxicity, had no effect on $\mathrm{fA} \beta$ binding (Fig. $1 C$ ), indicating that there was no trace contamination of CD14 ligands in the $\mathrm{A} \beta$ or antibody preparations.

\section{CD14, TLR4, and TLR2 are required for a fA $\beta$-induced phagocytic response}

Phagocytosis is the process by which cells ingest large particles $(>1 \mu \mathrm{m})$ in an actin-dependent manner (Aderem and Underhill,
1999), and is important for both the degradation of infectious agents (Aderem, 2002) and tissue maintenance. Numerous studies have demonstrated a requirement for TLRs in initiating phagocytosis of target pathogens (Heine et al., 1999; Underhill et al., 1999; Taborda and Casadevall, 2002; Blander and Medzhitov, 2004; Sendide et al., 2005; Neal et al., 2006). Fibrillar A $\beta$ stimulates microglial phagocytosis in a time- and dose-dependent manner (Kopec and Carroll, 1998). This response involves the microglial fA $\beta$ receptor complex via a $\beta_{1}$-integrin-dependent process (Koenigsknecht and Landreth, 2004) and requires Vav-mediated activation of Rac1 (Wilkinson et al., 2006). We wished to assess whether CD14, TLR4, and TLR2 participated in the initiation of this $\mathrm{fA} \beta$-stimulated response. BV 2 microglia were pretreated with function blocking antibodies to CD14, TLR4, or TLR2 before stimulation with fA $\beta$. Phagocytosis was monitored by the uptake of $1 \mu \mathrm{m}$ fluorescent beads (Fig. $2 A, B$ ). While fA $\beta$ resulted in increased bead uptake in control cells, CD14, TLR4, or TLR2 function blocking antibodies abrogated this response (Fig. 2A). Similarly, in primary microglial cultures prepared from wild-type, CD14 $4^{-/-}, \mathrm{TLR}^{-/-}$, or TLR $2^{-/-}$ animals, wild-type microglia demonstrated a robust phagocytic response following $\mathrm{fA} \beta$ stimulation (Fig. $2 C$ ). In contrast, $\mathrm{fA} \beta$ was unable to stimulate an increase in the phagocytic uptake of microspheres in $\mathrm{CD} 14^{-/-}, \mathrm{TLR} 4^{-/-}$, or $\mathrm{TLR} 2^{-/-}$microglia (Fig. 2C). These data indicate CD14, TLR4, and TLR2 are required at the cell surface to recognize $\mathrm{fA} \beta$ and to initiate a phagocytic response.

\section{ROS production stimulated by $\mathrm{fA} \beta$ requires CD14, TLR4, and TLR2}

To kill pathogens, microglia use the NADPH oxidase to generate superoxide, as well as the more potent ROS which arise from this free radical, including hydrogen peroxide, hydroxyl radical, peroxynitrite, and other oxidants (Bergendi et al., 1999). Microglia exposed to fA $\beta$ generate a respiratory burst and subsequent superoxide anion release via the microglial $\mathrm{fA} \beta$ cell surface receptor complex (Meda et al., 1996; McDonald et al., 1998; Bianca et al., 1999; Combs et al., 1999; Van Muiswinkel et al., 1999; Bamberger et al., 2003). We assessed the participation of CD14, TLR4, and TLR2 in this $\mathrm{fA} \beta$-stimulated response. Microglial cultures prepared from wild-type, CD $14^{-/-}$, TLR $4^{-/-}$, or TLR $2^{-/-}$animals were treated with $\mathrm{fA} \beta$, and the reduction of NBT to an insoluble formazan precipitant was used as a measure of intracellular superoxide radical generation. While fA $\beta$ resulted in a twofold increase in ROS production in wild-type microglia, it failed to stimulate superoxide radical formation in $\mathrm{CD} 14^{-/-}$, TLR $4^{-/-}$, or TLR ${ }^{-1-}$ microglia (Fig. 3A). LPS and Pam3CSK 4 were also able to drive ROS production in wild-type microglia but not in CD $14^{-l-}$ (Fig. 3B), TLR4 ${ }^{-l-}$ (Fig. 3C), or TLR2 ${ }^{-l-}$ microglia (Fig. 3D). The ability of phorbol ester PMA to activate PKC leading to NADPH oxidase assembly (McDonald et al., 1997; Bianca et al., 1999; Bamberger et al., 2003) provides a positive control for these studies. CD $14^{-1-}$, TLR $4^{-1-}$, or TLR $2^{-1-}$ microglia show a robust induction in ROS production following PMA, in a manner comparable to their wild-type counterparts, indicating the NADPH oxidase machinery is intact and functional in the microglia derived from knock-out animals (Fig. $3 B-D$ ). These data suggest CD14, TLR4, and TLR2 function as members of the microglial fA $\beta$ cell surface receptor complex that is functionally linked to ROS production. 
A

Control

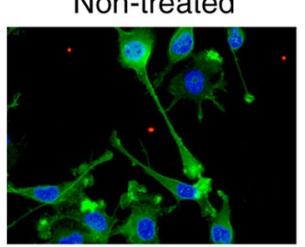

MY4

(CD14)

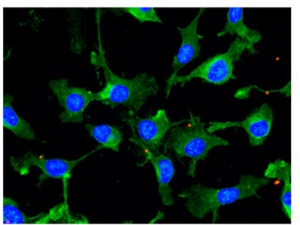

HTA125

(TLR4)

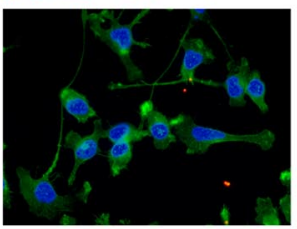

T2.5

(TLR2)
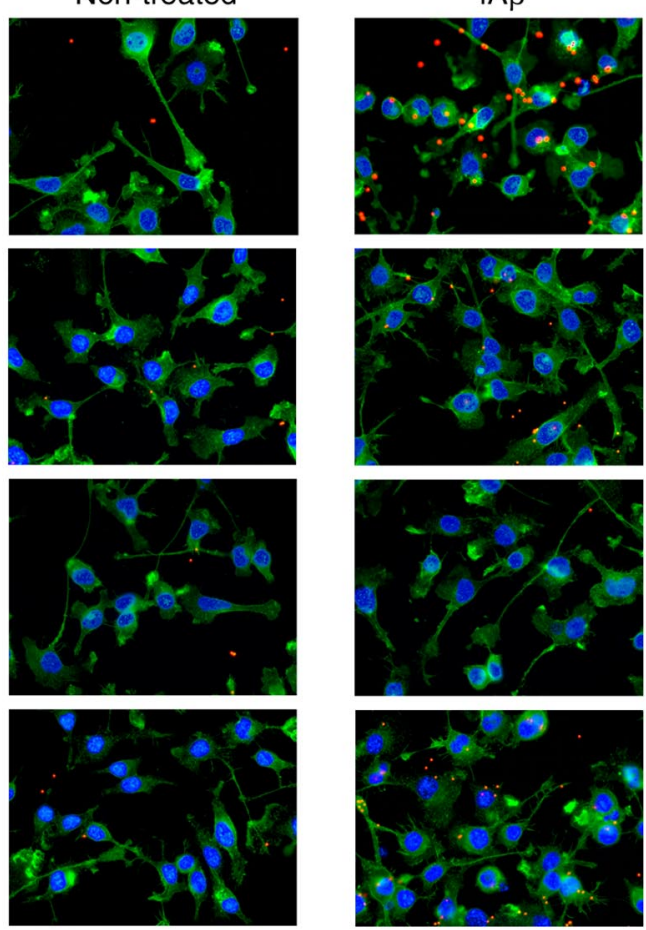

B

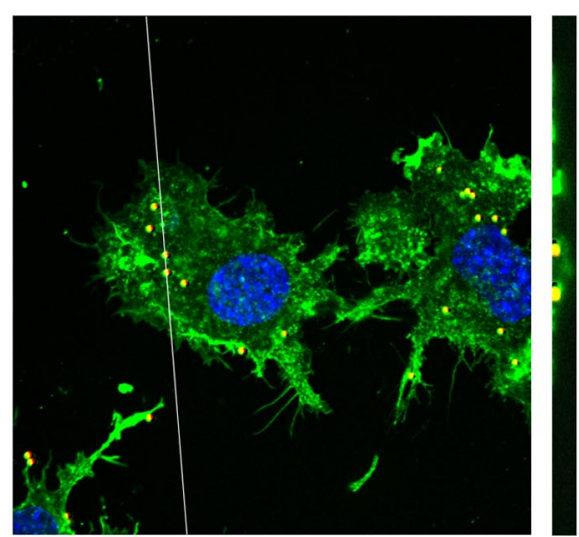

\section{C}

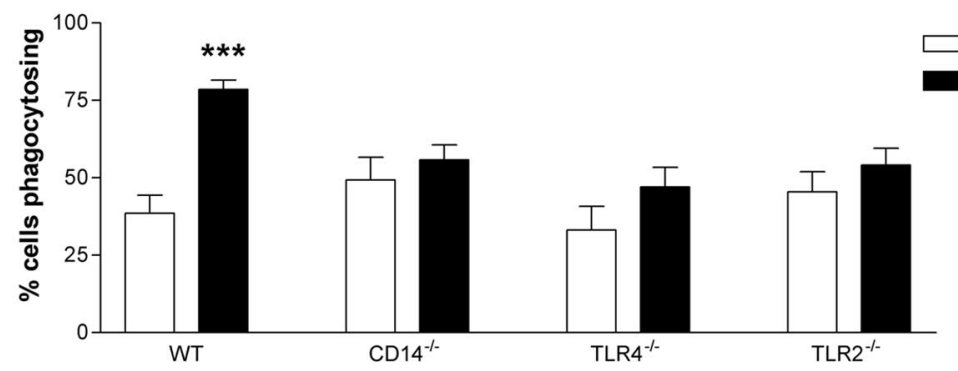

Figure 2. Phagocytosis stimulated by $f A \beta$ requires $C D 14, T L R 4$, and TLR2. A, BV2 microglia were pretreated with function blocking antibodies to CD14 (MY4), TLR4 (HTA125), or TLR2 (T2.5), before stimulation with FA $\beta$. Fluorescent microspheres were then added for $30 \mathrm{~min}$. Cells were stained with phalloidin for visualization of actin and DAPI. Magnification is $40 \times$. B, Confocal images $(100 \times)$ of BV2 microglia treated with $\mathrm{AA} \beta$-containing microspheres in both the $x-y$ plane (left) and $z$-scan cut (right) through the cells. C, Primary microglia from C57BL/6 (WT), CD14 ${ }^{-l-}$, TLR4 ${ }^{-1-}$, or TLR2 ${ }^{-1-}$ mice were stimulated with fA $\beta$, followed by incubation with fluorescent microspheres. The fraction of cells containing microspheres was determined by counting three random fields ( $>100$ cells) on an inverted microscope. The data shown are the mean \pm SEM of three independent experiments performed in duplicate. ${ }^{* *} p<0.001$ compared with Non-treated.

Initiation of the Src-Vav-Rac intracellular signaling cascade requires CD14, TLR4, and TLR2

Engagement of the microglial $\mathrm{fA} \beta$ receptor complex activates the Src family kinases Lyn and Fyn, and the Syk tyrosine kinase, which are required for subsequent signaling events (McDonald et al., 1997; Combs et al., 1999; Bamberger et al., 2003; Koenigsknecht and Landreth, 2004; Wilkinson et al., 2006). Interestingly, Src and Syk activation also occur following TLR engagement (English et al., 1993; Stefanová et al., 1993; Beaty et al., 1994). Therefore, we sought to determine whether CD14, TLR4, and TLR2 were required for the activation of Src following $\mathrm{f} A \beta$ stimulation using an antibody that cross-reacts with activated forms of the Src family members Lyn, Fyn, Lck, Yes, and Hck. While fA $\beta$ stimulated a twofold increase in the level of phosphorylated Src kinases in wild-type microglia, it had no effect on phospho-Src levels in $\mathrm{CD} 14^{-1-}, \mathrm{TLR}^{-1-}{ }^{-1}$, or TLR2 ${ }^{-1-}$ microglia (Fig. 4A). LPS, the canonical CD14 and TLR4 ligand, and Pam3CSK4, a synthetic TLR2-specific ligand, were also able to activate the Src kinases in wild-type microglia, but not in knock-out microglia (Fig. $4 B-D$ ) and provides a positive control for these studies. In contrast, immune IgG, which activates the Src kinase family through the Fc receptors (SánchezMejorada and Rosales, 1998), was able to drive Src phosphorylation in $\mathrm{CD} 14^{-/-}$, $\mathrm{TLR}^{-1-}$, and TLR2 ${ }^{-1-}$ microglia in a manner comparable to that of wild-type microglia (Fig. $4 B-D$ ), indicating Src is functionally linked to these receptors and the lack of a response to $\mathrm{A} A$ is reflective of the requirement for these receptors in mediating microglial signaling in response to this specific ligand.

Activation of these tyrosine kinases by $\mathrm{fA} \beta$ results in their association with the Rac-specific guanine nucleotide exchange factor Vav and its subsequent phosphorylation (Wilkinson et al., 2006). To determine whether the downstream target of these kinases was affected, we examined Vav phosphorylation following $\mathrm{fA} \beta$ treatment. Wild-type microglia respond to $\mathrm{fA} \beta$ by a twofold increase in Vav phosphorylation; however, microglia deficient in CD14, TLR4, or TLR2 did not exhibit Vav phosphorylation after $\mathrm{fA} \beta$ exposure (Fig. $5 A$ ).

The downstream target of Vav, the small GTPase Rac1, is GTP-loaded in a fA $\beta$-dependent manner and is translocated to the membrane where it mediates both actin reorganization necessary for phagocytosis and NADPH oxidase complex formation leading to ROS production (Wilkinson et al., 2006). We found that while $\mathrm{fA} \beta$ stimulated a twofold increase in membrane-associated Rac in wild-type microglia, it was unable to do so in $\mathrm{CD}_{14}{ }^{-/-}$, $\mathrm{TLR}_{4}^{-l-}$, or TLR2 ${ }^{-/-}$microglia (Fig. $5 B$ ). These data demonstrate that the absence of CD14, TLR4, or TLR2 from the microglial cell surface prevents the receptor complex from initiating the Src-Vav-Rac intracellular signaling cascade. 
A

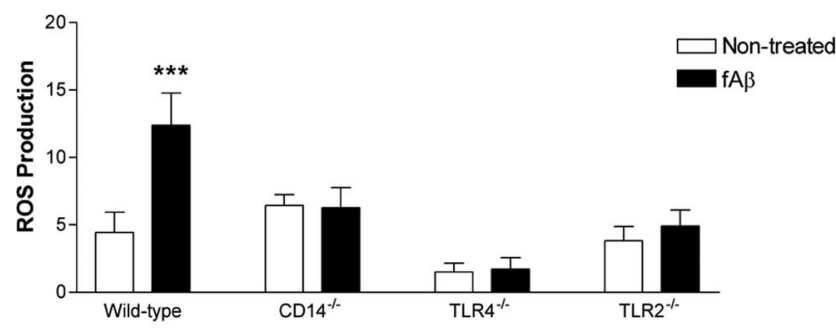

$\mathrm{B}$

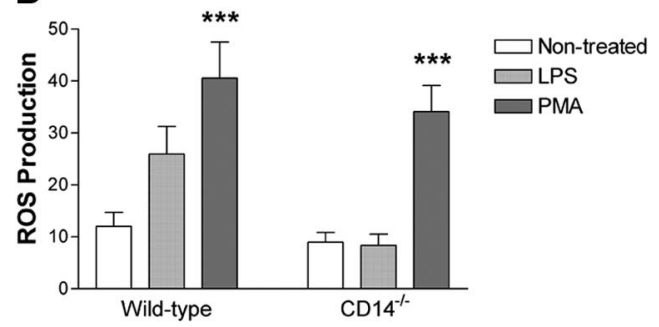

C

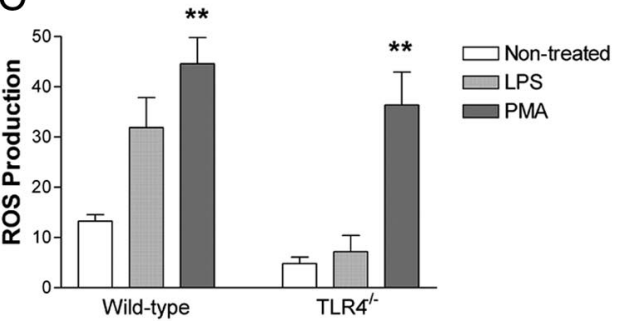

D

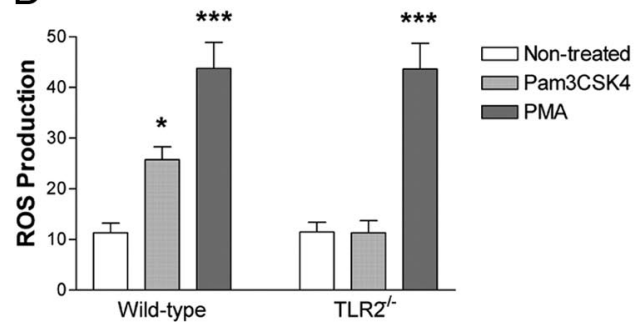

Figure 3. $C D 14$, TLR4, and TLR2 are necessary for $\mathrm{AA} \beta$-stimulated reactive oxygen species production. $A-D$, Primary microglia from $\mathrm{C57BL} / 6(\mathrm{WT}), \mathrm{CD} 4^{-1-}, \mathrm{TLR}^{-1-}$, $\mathrm{TLR}^{-1-}$ mice were stimulated with $\mathrm{fA} \beta(\boldsymbol{A})$, LPS $(\boldsymbol{B}, \boldsymbol{C})$, Pam3CSK4 (D), or PMA (B-D). Reduction of NBT results in the formation of a dark blue formazan deposit viewable by a light microscope. Three random fields (>100 cells) were counted and the fraction of cells with blue formazan deposits was determined. The data shown are the mean \pm SEM of three independent experiments performed in duplicate. ${ }^{*} p<0.05,{ }^{* *} p<0.01,{ }^{* * *} p<0.001$ compared with Non-treated.

\section{Activation of p38 MAPK by $\mathrm{fA} \beta$ is reduced in $\mathrm{CD} 14^{-/-}$,} TLR4 $^{-1-}$, and TLR2 ${ }^{-1-}$ microglia

The MAP kinase $\mathrm{p} 38$ is activated in microglia in response to $\mathrm{fA} \beta$ in vitro (McDonald et al., 1997; Pyo et al., 1998). Activated forms of $\mathrm{p} 38$ are found in the brains of $\mathrm{AD}$ mouse models and $\mathrm{AD}$ patients (Hensley et al., 1999; Zhu et al., 2000; Savage et al., 2002; Giovannini et al., 2002; Sun et al., 2003; Ferrer, 2004; Jin et al., 2005). Moreover, p38 is activated following engagement of the TLRs in a manner similar to that elicited by $\mathrm{fA} \beta$ exposure (Bhat et al., 1998; Pyo et al., 1998; Kim et al., 2004). We assessed levels of phosphorylated $\mathrm{p} 38$ in $\mathrm{CD} 14^{-1-}$, $\mathrm{TLR}^{-1-}$, and TLR2 $2^{-1-} \mathrm{mi}-$ croglia following fA $\beta$ treatment, and found that, compared with their wild-type counterparts, these microglia failed to show an increase in phospho-p38 (Fig. 6A). Similarly, CD14/TLR4 and TLR2 ligands LPS (Fig. 6B,C) and Pam3CSK4 (Fig. 6D) increased the levels of phosphorylated p38 in wild-type microglia,
A

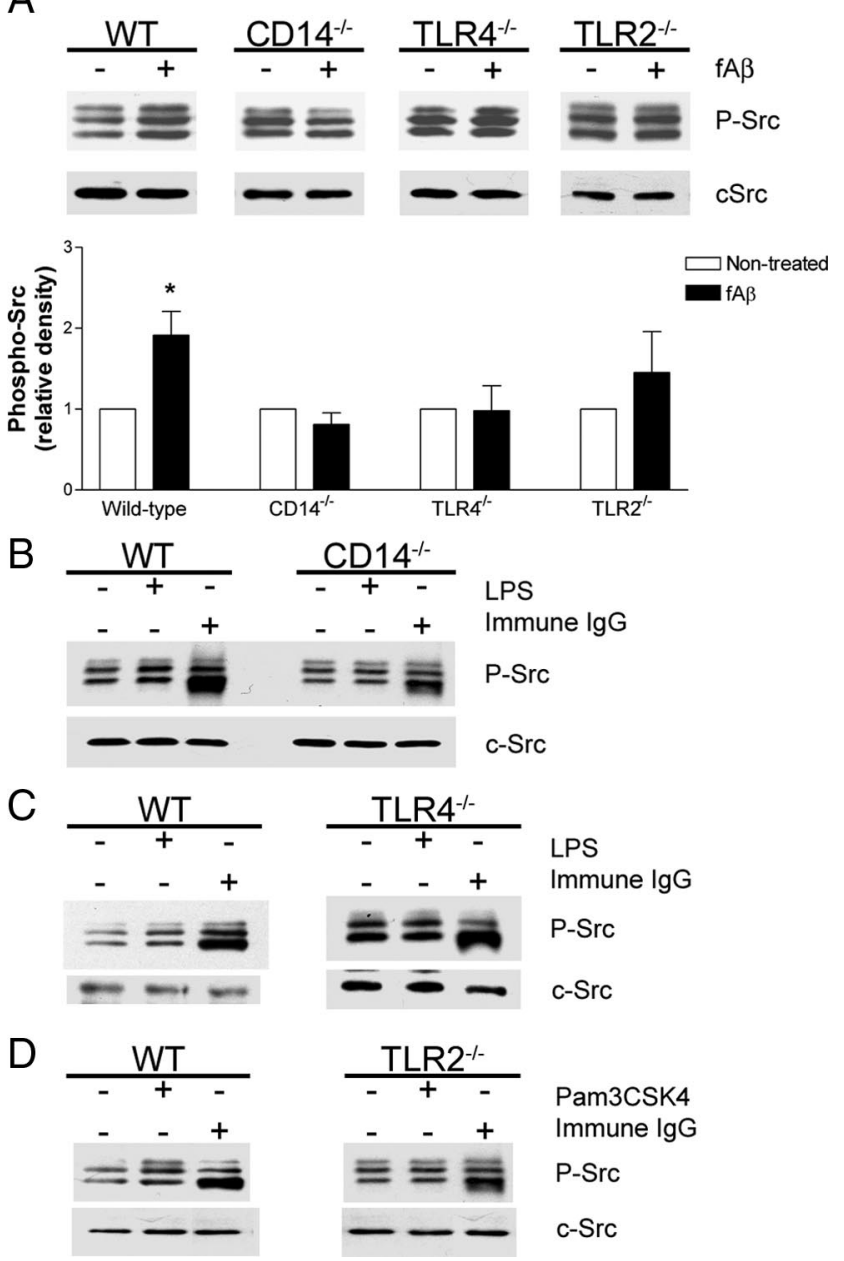

Figure 4. Activation of the $S r c$ tyrosine kinases by $\mathrm{fA} \beta$ requires $C D 14, T L R 4$, and TLR2. $A-D$, Primary microglia from C57BL/6 (WT), $\mathrm{CD}^{4} 4^{-1-}$, $\mathrm{TLR}^{-1-}$, or TLR2 ${ }^{-1-}$ mice were stimulated with $\mathrm{fA} \beta(\boldsymbol{A}), \mathrm{LPS}(\boldsymbol{B}, \boldsymbol{C}), \operatorname{Pam} 3 \mathrm{CSK} 4(\boldsymbol{D})$, or immune lgG $(\boldsymbol{B}-\boldsymbol{D})$. Cell lysates were analyzed by Western blot analysis using an anti-phospho-Src family antibody. Blots were stripped and reprobed with an anti-cSrc antibody as a protein loading control. $\boldsymbol{A}$, Western blot band intensity of phosphorylated Src kinases was normalized to $\mathrm{C}$ Src levels and expressed as relative density. Western blots are representative, and the densitometry data are the mean \pm SEM from at least three independent experiments. ${ }^{*} p<0.05$ compared with Non-treated.

but not in $\mathrm{CD} 14^{-1-}$, TLR $4^{-1-}$, and TLR2 ${ }^{-1-}$ microglia. However, immune IgG was able to induce levels of phospho-p38 in the receptor-deficient cells (Fig. 6B-D) as previously reported (Yamamori et al., 2000), indicating p38 MAP kinase signaling pathways are intact in these cells and the failure to activate p38 is specifically abrogated in response to $\mathrm{fA} \beta$.

\section{Inhibition of $\mathrm{p} 38$ attenuates $\mathrm{fA} \beta$-stimulated ROS production} and phagocytosis

We used a p38-specific inhibitor, SB203580, to elucidate the role of p38 in $\mathrm{fA} \beta$-induced ROS production. Previous work has shown that $\mathrm{p} 38$ phosphorylates the $\mathrm{p} 47^{\text {phox }}$ subunit of the NADPH oxidase complex (El Benna et al., 1996; Dang et al., 2006). Phosphorylation of $\mathrm{p} 7^{\text {phox }}$ serine residues exposes binding domains that interact with other cytoplasmic NADPH oxidase subunits and phosphoinositide lipid products, resulting in $\mathrm{p} 47^{\text {phox }}$ translocation to the membrane, where it participates in NADPH oxidase complex assembly (DeLeo and Quinn, 1996; Sumimoto et al., 1996; Ago et al., 1999, 2003; Babior, 1999). Significantly, this occurs following LPS engagement of CD14 


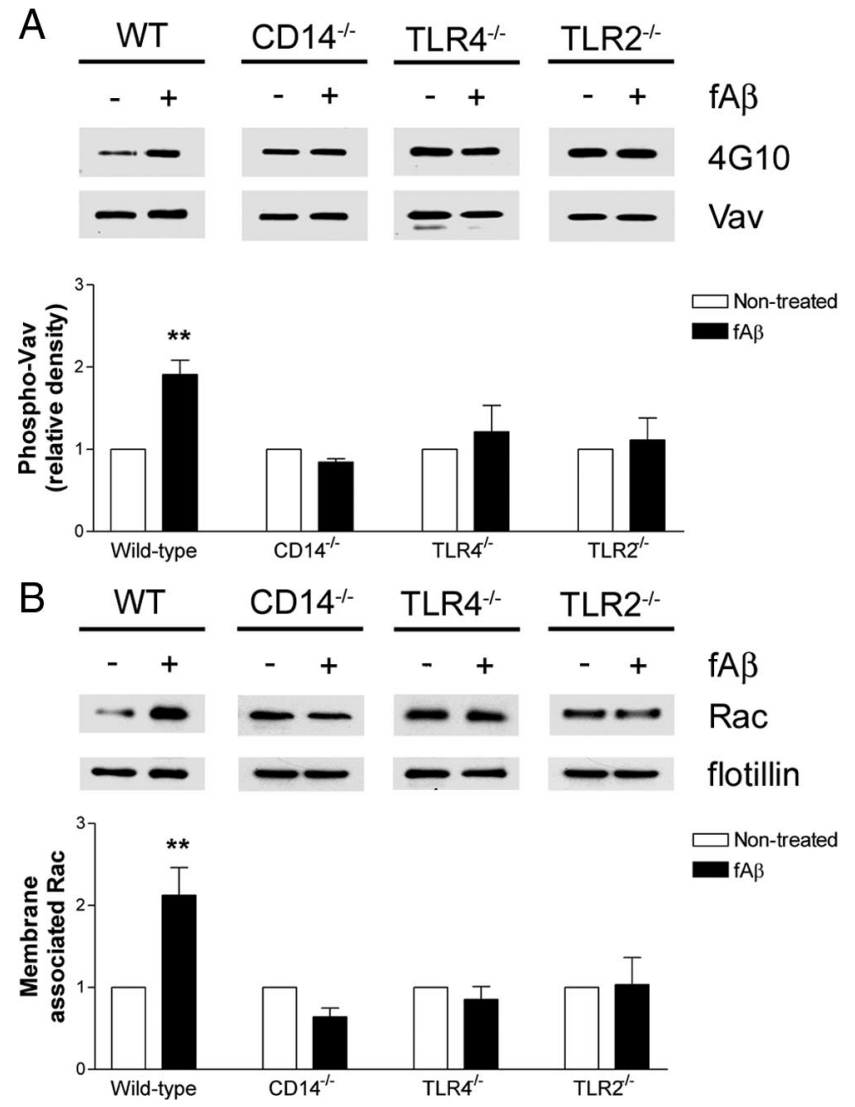

Figure 5. CD14, TLR4, and TLR2 are required for $\mathrm{AA} \beta$-induced phosphorylation of the Rac GEF Vav and subsequent translocation of Rac to the membrane. $A$, Primary microglia from $\mathrm{C} 57 \mathrm{BL} / 6$ (WT), $\mathrm{CD} 14^{-1-}, \mathrm{TLR}^{-1-}$, or TLR2 ${ }^{-1-}$ mice were stimulated with $\mathrm{fA} \beta$. Vav was immunoprecipitated from cell lysates with an anti-Vav antibody and analyzed by Western blot analysis using the anti-phosphoTyr antibody 4G10. Blots were stripped and reprobed with an anti-Vav antibody as a protein loading control. B, Primary microglia from C57BL/6 (WT), $\mathrm{CD}_{14}{ }^{-1-}$, $\mathrm{TLR}^{-1-}$, or TLR2 ${ }^{-1-}$ mice were stimulated with $\mathrm{fA} \beta$. Membrane fractions were analyzed by Western blot analysis with an anti-Rac antibody and an anti-flotillin antibody as a protein loading control. Western blots are representative, and the densitometry data are the mean \pm SEM from three independent experiments. ${ }^{* *} p<0.01$ compared with Non-treated.

(Yan et al., 2002; Laroux et al., 2005). The p38 inhibitor SB203580 prevented fA $\beta$-induced ROS production (Fig. 7A), consistent with a previous report using a different p38 inhibitor (Smits et al., 2001).

Next, the role of $\mathrm{p} 38$ in $\mathrm{fA} \beta$-induced phagocytosis was assessed. Activation of p38 MAPK is required for cytoskeleton rearrangement and subsequent autophagy (Park et al., 2008; Tang et al., 2008). The small GTPase Rac has been implicated in membrane ruffling and phagocytosis (Ridley et al., 1992; Cox et al., 1997), and its activation by GTP-loading and cytosol to membrane translocation is regulated by p38 activity (El Bekay et al., 2007; Zuluaga et al., 2007; Osada et al., 2009). To assess whether $\mathrm{fA} \beta$-stimulated $\mathrm{p} 38$ activation via the $\mathrm{fA} \beta$ receptor complex modulated phagocytosis, we treated microglia with the p38 inhibitor SB203580 before fA $\beta$ stimulation. Consistent with work that showed inhibition of $\mathrm{p} 38$ attenuated LPS-driven phagocytosis (Kong and Ge, 2008), we found that SB203580 reduced fA $\beta$ stimulated microsphere uptake (Fig. 7B).

\section{CD14, TLR4, and TLR2 in fA $\beta$-induced NF $\kappa$ B activation}

Engagement of CD14 and Toll-like receptors is known to stimulate $\mathrm{NF} \kappa \mathrm{B}$-dependent transcription (Akira, 2001; Medzhitov, 2001). Fibrillar $A \beta$ has also been shown to activate
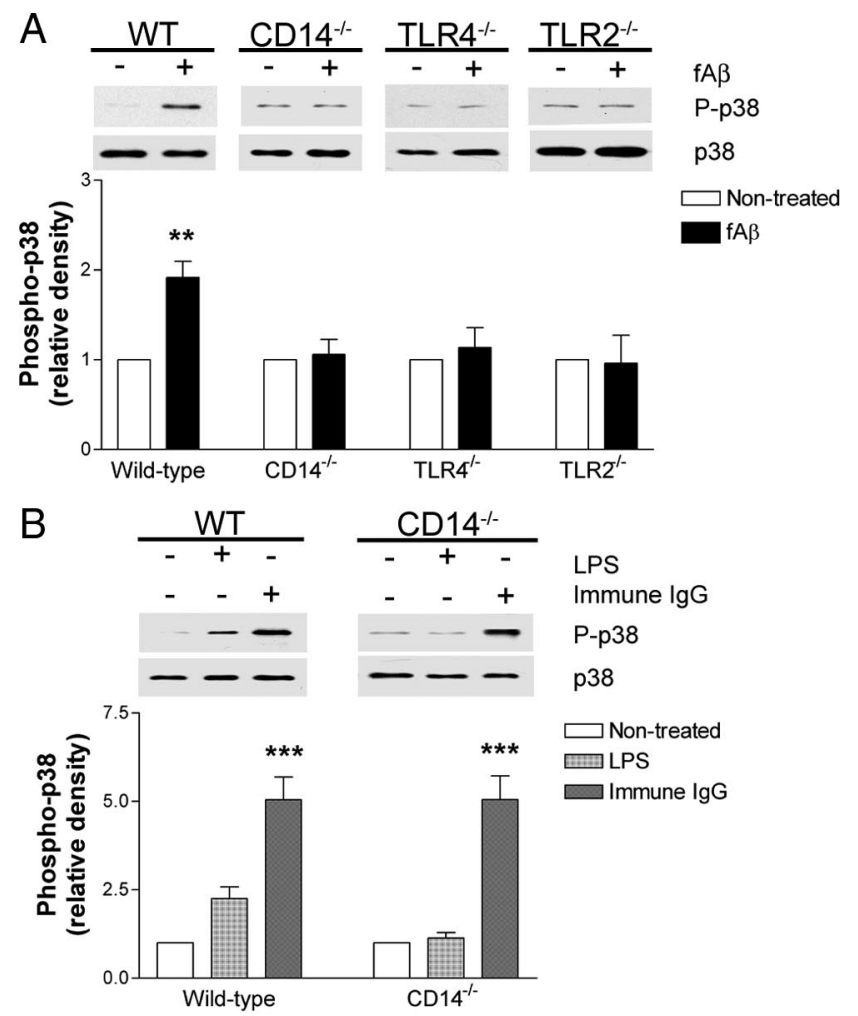

C

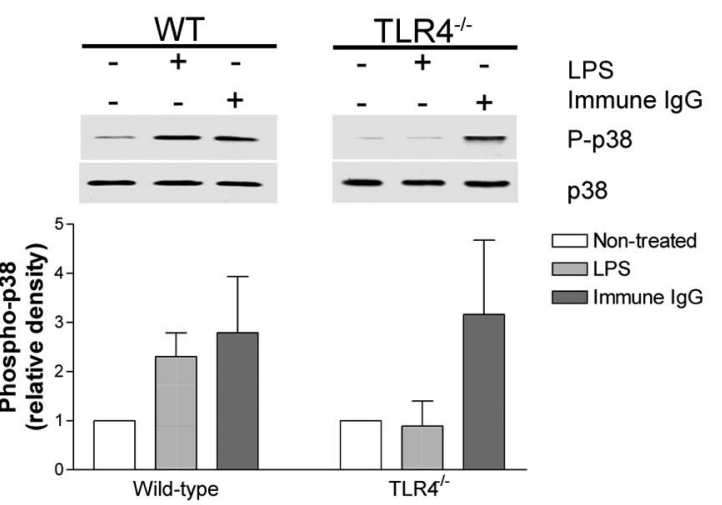

D

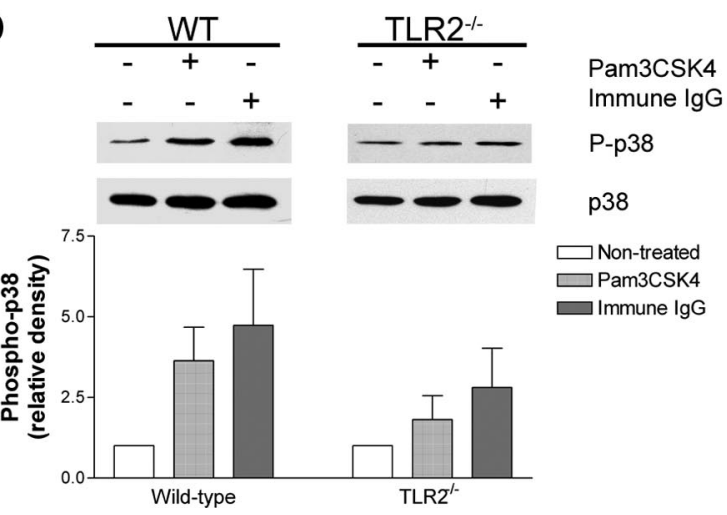

Figure 6. Activation of the $\mathrm{p} 38 \mathrm{MAP}$ kinase by $\mathrm{fA} \beta$ requires $\mathrm{CD} 14$, TLR4, and TLR2. $\boldsymbol{A}-\boldsymbol{D}$, Primary microglia from C57BL/6 (WT), CD14 ${ }^{-1-}, \mathrm{TLR}^{-1-}$, or TLR2 ${ }^{-1-}$ mice were stimulated with $\mathrm{fA} \beta(\boldsymbol{A}), \mathrm{LPS}(\boldsymbol{B}, \boldsymbol{C}), \operatorname{Pam} 3 \mathrm{CSK} 4(\boldsymbol{D})$, or immune lgG $(\boldsymbol{B}-\boldsymbol{D})$. Cell lysates were analyzed by Western blot analysis using an anti-phospho-p38 antibody. Blots were stripped and reprobed with an anti-p38 antibody as a protein loading control. Western blot band intensity of phosphorylated-p38 was normalized to $\mathrm{p} 38$ levels and expressed as relative density. Western blots are representative, and the densitometry data are the mean \pm SEM from at least three independent experiments. ${ }^{* *} p<0.01,{ }^{* * *} p<0.001$ compared with Non-treated. 


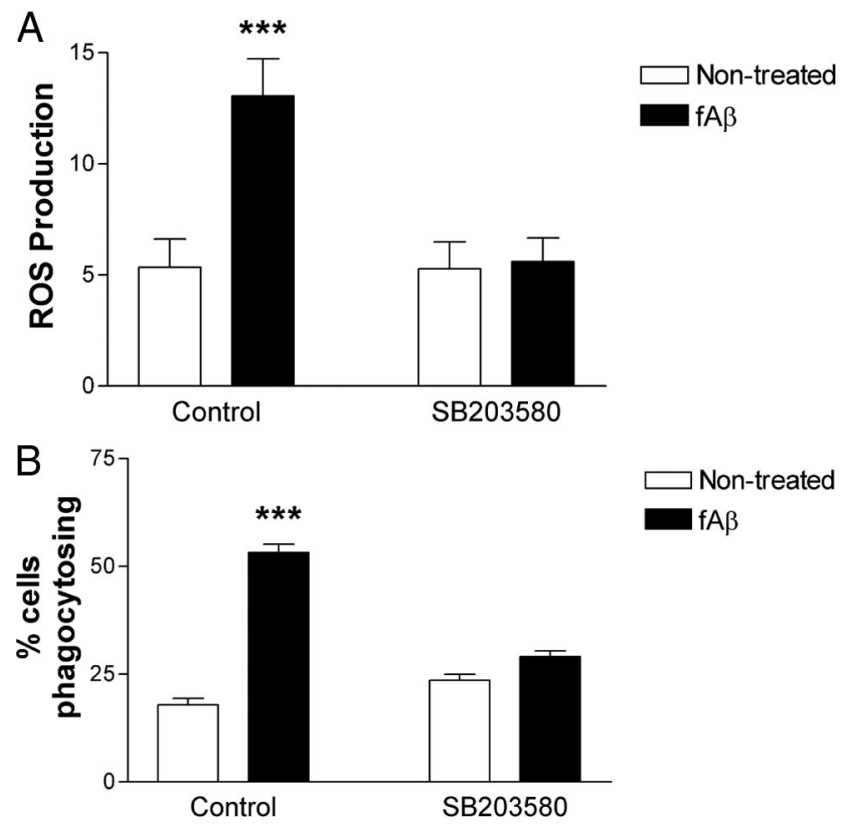

Figure 7. Fibrillar $A \beta$-stimulated ROS production and phagocytosis requires the activity of p38. $A$, Primary microglia from C57BL/6 mice were pretreated with SB203580 before stimulation with $\mathrm{fA} \beta$. Reduction of NBT results in the formation of a dark blue formazan deposit viewable by a light microscope. Three random fields ( $>100$ cells) were counted and the fraction of cells with blue formazan deposits was determined. The data shown are the mean \pm SEM of three independent experiments performed in duplicate. ${ }^{* * *} p<0.001$ compared with Nontreated. $\boldsymbol{B}, \mathrm{BV} 2$ microglia were pretreated with SB203580 before stimulation with $\mathrm{fA} \beta$. Fluorescent microspheres were added, following which the fraction of cells containing microspheres was determined by counting three random fields ( $>100$ cells) on an inverted microscope. The data shown are the mean \pm SEM of three independent experiments performed in duplicate. ${ }^{* * *} p<0.001$ compared with Non-treated.

$\mathrm{NF} \kappa \mathrm{B}$ in monocytes and microglia (Combs et al., 2001). Inhibition of CD14, TLR4, and TLR2 prevents $\mathrm{A} \beta$-stimulated NF $\kappa \mathrm{B}$ dependent gene induction (Fassbender et al., 2004; Walter et al., 2007; Jana et al., 2008; Udan et al., 2008). NFкB is held in an inactive state in the cytosol by its participation in a complex with the inhibitory $\mathrm{I} \kappa \mathrm{B}$ proteins (Baeuerle and Baltimore, 1988; Beg and Baldwin, 1993; Finco et al., 1994). I $\kappa \mathrm{B} \alpha$ is phosphorylated at Ser32 and Ser36, resulting in dissolution of the complex and targeting $\mathrm{IkBa}$ for proteosome-mediated degradation, and thereby permitting $\mathrm{NF} \kappa \mathrm{B}$ nuclear translocation for transcription (Finco et al., 1994; Brockman et al., 1995; Brown et al., 1995; Traenckner et al., 1995; Chen et al., 1996). We assessed NFкB activation by measuring $\mathrm{I} \kappa \mathrm{B} \alpha$ phosphorylation following $\mathrm{fA} \beta$ stimulation. Wild-type microglia responded to fA $\beta$ with a twofold increase in phospho-I $\kappa \mathrm{B} \alpha$ levels; however, CD14-, TLR4-, or TLR2-deficient microglia did not show increased I $\kappa \mathrm{B} \alpha$ phosphorylation following fA $\beta$ exposure (Fig. 8). These data are consistent with previous reports demonstrating a requirement for CD14, TLR4, and TLR2 in fA $\beta$-stimulated NF $\kappa$ B-dependent transcription (Fassbender et al., 2004; Walter et al., 2007; Jana et al., 2008; Udan et al., 2008).

\section{Discussion}

The inflammatory component of $\mathrm{AD}$ reflects the response of microglial cells to deposits of $\mathrm{fA} \beta$. The current study demonstrates an essential role for canonical innate immune receptors in the induction of the microglial inflammatory response. These results are consistent with findings of how immune cells recognize pathogens and other complex entities, namely through the use of

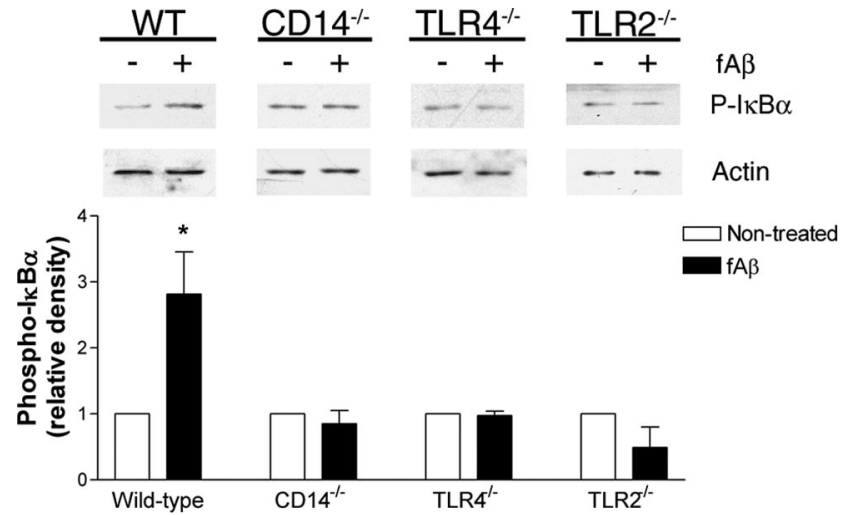

Figure 8. $\quad C D 14, T L R 4$, and TLR2 are required for $\mathrm{fA} \beta$-induced $\mathrm{NF} \kappa \mathrm{B}$ activation. Primary microglia from C57BL/6 (WT), CD14 ${ }^{-1-}$, TLR4 ${ }^{-1-}$, or TLR2 $2^{-1-}$ mice were stimulated with $\mathrm{fA} \beta$. Cell lysates were analyzed by Western blot analysis using an anti-phospho-I $\kappa \mathrm{B} \alpha$ antibody. Blots were stripped and reprobed with an anti-actin antibody as a protein loading control. Western blot band intensity of phosphorylated- $-\kappa \mathrm{B} \alpha$ was normalized to actin levels and expressed as relative density. Western blots are representative, and the densitometry data represent the mean \pm SEM from at least three independent experiments. ${ }^{*} p<0.05$ compared with Non-treated.

receptor ensembles. Immune cells often use ensembles of receptors to bind fibrillar proteins and other complex macromolecules (Ishibashi et al., 1994; Bornstein, 1995; Wong et al., 1996). TLRs act in concert with other immune receptors to form large receptor complexes whose composition is governed by the ligand that is engaged (Pfeiffer et al., 2001; Triantafilou et al., 2006). This combinatorial use of cell surface receptors determines the character of the immune response (Triantafilou et al., 2004). We have previously described a multireceptor complex on the surface of microglia consisting of the $\alpha_{6} \beta_{1}$ integrin, the integrin associated protein $\mathrm{CD} 47$, the $\mathrm{B}$-class scavenger receptor CD36, and SRA (Bamberger et al., 2003). We demonstrate an obligatory role for CD14 in microglial recognition of $\mathrm{fA} \beta$ and mounting a cellular response to this ligand. The roles of CD14 and scavenger receptors have been confounded by the use of fucoidan, which has historically been used to inhibit the binding of various ligands to scavenger receptors. It is well appreciated that it also inhibits the ability of CD14 to bind its ligands (Heinzelmann et al., 1998; Gregory and Devitt, 1999; van Oosten et al., 2001). Many of the reports of SRA-dependent signaling have been misinterpreted and are due to CD14 interacting with other scavenger receptor ligands (Kim et al., 2003). Importantly, CD14 has been shown to associate with CD36 and CD47 in response to various ligands (Pfeiffer et al., 2001) and bind fibrillar forms of $A \beta$ (Fassbender et al., 2004), observations consistent with our postulate that these receptors act in concert to bind $\mathrm{fA} \beta$ and initiate intracellular signaling. The well documented functional interactions of CD14 with TLR4 or TLR2 led us to investigate their participation in a receptor complex mediating the microglial response to fA $\beta$.

We report that CD14, TLR4, and TLR2 are necessary for binding $\mathrm{fA} \beta$ at the cell surface, and are required for phenotypic activation of microglia and induction of phagocytosis. Microglia are competent phagocytes, reflective of their roles as the brain's principal immune effector cell (Streit et al., 2004). We have previously demonstrated the $\mathrm{fA} \beta$-stimulated induction of phagocytosis via the $\mathrm{fA} \beta$ receptor complex that was reliant upon the action of the $\beta_{1}$ integrin (Koenigsknecht and Landreth, 2004). Similarly, microglial activation by TLR ligands was reported to stimulate $\mathrm{A} \beta$ uptake (Tahara et al., 2006), although it is unclear whether this is through macropinocytosis (Mandrekar et al., 2009) or phagocy- 
tosis of $A \beta$. One caveat with this and other in vitro studies is that they employ microglia derived from neonatal animals. A significant issue in the interpretation of these data is that they might not accurately reflect the activities of these cells in vivo in aged animals. Moreover, there is evidence that microglia from aged animals have reduced phagocytic capacity and blunted induction of cytokine expression (Floden and Combs, 2006; Sierra et al., 2007). Indeed, work by Flanary et al. (2007) has demonstrated that microglia can undergo senescence in aged animals. However, a recent study by Sierra et al. (2007) suggests that the effect of aging is principally to reduce the magnitude of microglial responses to inflammatory stimuli, without changing the nature or specificity of the response.

Fibrillar $\mathrm{A} \beta$ and TLR ligands both stimulate NADPH oxidase to form superoxide and more potent ROS. We demonstrated that CD14, TLR4, and TLR2 are necessary for fA $\beta$ to stimulate this response. These findings differ from those reported by Qin et al. (2005) who found LPS-induced superoxide production by microglia was independent of TLR4. There are two significant differences in the studies that may explain this discrepancy. Qin et al. used $\mathrm{C} 3 \mathrm{H} / \mathrm{HeJ}$ mice, which express a mutated and functionally impaired form of TLR4, while the mice used here were TLR4-null and on a B6 background. Moreover, these two studies used different forms of LPS, and LPS structure can influence the immune pathways activated by the various species (Gangloff et al., 1999). Different LPS analogues trigger the recruitment of different receptor ensembles within membrane microdomains, and the composition of each receptor cluster determines the nature of the immune response (Triantafilou et al., 2004).

Signal transduction cascades activated by TLR engagement are indistinguishable from those activated by fA $\beta$. (English et al., 1993; Stefanová et al., 1993; Beaty et al., 1994; Geng et al., 1994; Arbibe et al., 2000; Lee et al., 2000; Sanlioglu et al., 2001; Wilkinson et al., 2006). Therefore, we tested whether CD14, TLR4, and TLR 2 participated in fA $\beta$-stimulated signaling. Significantly, we found that each of these receptors were required. Thus, these innate immune receptors not only function in binding $\mathrm{fA} \beta$, but are essential for the $\mathrm{fA} \beta$-stimulated activation of the Src-Vav-Rac signaling cascade, just as are other members of the $\mathrm{fA} \beta$ receptor complex. A primary downstream target of both $\mathrm{fA} \beta$ receptor signaling and TLRs is the p38 MAPK (McDonald et al., 1997; Pyo et al., 1998). We demonstrate that CD14, TLR4, and TLR2 were required for $\mathrm{fA} \beta$-induced activation of $\mathrm{p} 38$, which is required for $\mathrm{fA} \beta$-induced reactive oxygen species production. We also demonstrate that inhibition of p38 activity reduces $\mathrm{fA} \beta$-stimulated phagocytosis. These observations are consistent with the roles of p38 in the immune response.

We report a requirement for CD14, TLR4, and TLR2 in NF $\kappa \mathrm{B}$ activation following $\mathrm{fA} \beta$. NF $\kappa \mathrm{B}$ becomes transcriptionally active following phosphorylation of its inhibitor $\mathrm{I} \kappa \mathrm{B} \alpha$, which targets it for degradation, permitting nuclear translocation of $\mathrm{NF} \kappa \mathrm{B}$ (Baeuerle and Baltimore, 1988; Beg and Baldwin, 1993; Finco et al., 1994; Brockman et al., 1995; Brown et al., 1995; Traenckner et al., 1995; Chen et al., 1996). Fibrillar A $\beta$ has been shown to stimulate NFкB-dependent gene expression via CD14, TLR4, and TLR2 (Fassbender et al., 2004; Walter et al., 2007; Jana et al., 2008; Udan et al., 2008). We extend these studies by showing these receptors are also required for the activation of $\mathrm{I} \kappa \mathrm{B} \alpha$, which is required for $\mathrm{NF} \kappa \mathrm{B}$ nuclear translocation and subsequent target gene transcription.

A number of recent studies have assessed whether the innate immune system is involved in $\mathrm{AD}$. There is increased expression of CD14, TLR2, and TLR4 in the brains both animal models of
AD as well as AD patients (Fassbender et al., 2004; Liu et al., 2005; Walter et al., 2007; Letiembre et al., 2009). Moreover, a polymorphism in the TLR4 gene results in a blunted signaling response and is correlated with a 2.7-fold reduction in risk for late onset $\mathrm{AD}$ (Minoretti et al., 2006). CD14, when overexpressed in $\mathrm{CHO}$ cells, has been shown to bind A $\beta$ (Fassbender et al., 2004). This coreceptor has also been shown to be necessary for release of nitrite and proinflammatory gene expression from microglia (Fassbender et al., 2004; Liu et al., 2005). There is evidence that TLRs are involved in the microglial response to $A \beta$ as inhibition of TLR 4 or TLR2 through function blocking antibodies or siRNA knock-down also prevented $\mathrm{fA} \beta$-induced nitrite, IL-6, and TNF- $\alpha$ production (Walter et al., 2007; Jana et al., 2008; Udan et al., 2008). These effects were dependent on the fibrillar structure of $A \beta$ (Fassbender et al., 2004; Walter et al., 2007). The role of TLRs in $\mathrm{A} \beta$ clearance in vivo was examined by two separate studies with seemingly different outcomes. Fourteen- to 16-month-old APPswe/PSENdE9 mice with inactive TLR4 showed increased cortical and hippocampal $\mathrm{A} \beta$ burden, without changing steadystate APP or presenilin 1 levels, arguing that the change in A $\beta$ load was due to a change in microglial-mediated $\mathrm{A} \beta$ clearance that is reliant upon TLR4 function (Tahara et al., 2006). In contrast, APPswe/PSENdE9 mice lacking TLR2 had delayed plaque formation through 6 months of age, but by 9 months the plaque deposition was comparable to their wild-type counterparts (Richard et al., 2008). This suggests that during early stages of AD, TLRindependent $\mathrm{A} \beta$ clearance mechanisms are effective in removing $\mathrm{A} \beta$ from the brain, and potentially, the absence of TLR-mediated inflammation makes these processes more efficient. However, over the course of time, the rate of $\mathrm{A} \beta$ production overwhelms these processes and the lack of TLRs enhances $A \beta$ deposition. A recent study by Scholtzova et al. (2009) reported that intraperitoneal injections of TLR9 ligands into a murine model of AD resulted in behavioral improvement and reduction of amyloid burden in the brain; however, the mechanism through which the effects are achieved are unknown since the TLR9 ligands are not likely to have entered the brain.

The present study places the innate immune receptors CD14, TLR4, and TLR 2 at the interface of microglia and $\mathrm{fA} \beta$, consistent with previous reports. Importantly, this study extends what is known about the mechanisms behind these receptors in microglial activation. CD14, TLR4, and TLR2 function along with CD36, the $\alpha_{6} \beta_{1}$ integrin, and CD47 as members of the $\mathrm{fA} \beta$ receptor complex whose engagement initiates the parallel signaling cascades of Src-Vav-Rac and the p38 MAP kinase for the induction of ROS, phagocytosis, and $\mathrm{NF} \kappa \mathrm{B}$ activation. While an acute inflammatory response eliminates pathogens and promotes tissue repair and is therefore neuroprotective, chronic inflammation results in progressive damage and is associated with neurotoxicity (Akiyama et al., 2000). These findings provide an understanding for the role of the innate immune system in the acute inflammatory reaction to $\mathrm{fA} \beta$, allowing for the development of effective therapeutic strategies to control the inflammatory aspect of AD.

\section{References}

Aderem A (2002) How to eat something bigger than your head. Cell 110:5-8.

Aderem A, Underhill DM (1999) Mechanisms of phagocytosis in macrophages. Annu Rev Immunol 17:593-623.

Ago T, Nunoi H, Ito T, Sumimoto H (1999) Mechanism for phosphorylationinduced activation of the phagocyte NADPH oxidase protein p47(phox). Triple replacement of serines 303, 304, and 328 with aspartates disrupts the $\mathrm{SH} 3$ domain-mediated intramolecular interac- 
tion in 447 (phox), thereby activating the oxidase. J Biol Chem 274:33644-33653.

Ago T, Kuribayashi F, Hiroaki H, Takeya R, Ito T, Kohda D, Sumimoto H (2003) Phosphorylation of p47phox directs phox homology domain from SH3 domain toward phosphoinositides, leading to phagocyte NADPH oxidase activation. Proc Natl Acad Sci U S A 100:4474-4479.

Akira S (2001) Toll-like receptors and innate immunity. Adv Immunol $78: 1-56$.

Akiyama H, Barger S, Barnum S, Bradt B, Bauer J, Cole GM, Cooper NR, Eikelenboom P, Emmerling M, Fiebich BL, Finch CE, Frautschy S, Griffin WS, Hampel H, Hull M, Landreth G, Lue L, Mrak R, Mackenzie IR, McGeer PL, et al. (2000) Inflammation and Alzheimer's disease. Neurobiol Aging

383-421.

Arbibe L, Mira JP, Teusch N, Kline L, Guha M, Mackman N, Godowski PJ, Ulevitch RJ, Knaus UG (2000) Toll-like receptor 2-mediated NFkappa $B$ activation requires a Rac1-dependent pathway. Nat Immunol 1:533-540

Babior BM (1999) NADPH oxidase: an update. Blood 93:1464-1476.

Baeuerle PA, Baltimore D (1988) I kappa B: a specific inhibitor of the NFkappa B transcription factor. Science 242:540-546.

Bamberger ME, Harris ME, McDonald DR, Husemann J, Landreth GE (2003) A cell surface receptor complex for fibrillar beta-amyloid mediates microglial activation. J Neurosci 23:2665-2674.

Beaty CD, Franklin TL, Uehara Y, Wilson CB (1994) Lipopolysaccharideinduced cytokine production in human monocytes: role of tyrosine phosphorylation in transmembrane signal transduction. Eur J Immunol 24:1278-1284.

Beg AA, Baldwin AS Jr (1993) The I kappa B proteins: multifunctional regulators of Rel/NF-kappa B transcription factors. Genes Dev 7:2064-2070.

Bergendi L, Benes L, Duracková Z, Ferencik M (1999) Chemistry, physiology and pathology of free radicals. Life Sci 65:1865-1874.

Bhat NR, Zhang P, Lee JC, Hogan EL (1998) Extracellular signal-regulated kinase and p38 subgroups of mitogen-activated protein kinases regulate inducible nitric oxide synthase and tumor necrosis factor-alpha gene expression in endotoxin-stimulated primary glial cultures. J Neurosci 18:1633-1641.

Bianca VD, Dusi S, Bianchini E, Dal Prà I, Rossi F (1999) beta-amyloid activates the O-2 forming NADPH oxidase in microglia, monocytes, and neutrophils. A possible inflammatory mechanism of neuronal damage in Alzheimer's disease. J Biol Chem 274:15493-15499.

Blander JM, Medzhitov R (2004) Regulation of phagosome maturation by signals from toll-like receptors. Science 304:1014-1018.

Blasi E, Barluzzi R, Bocchini V, Mazzolla R, Bistoni F (1990) Immortalization of murine microglial cells by a v-raf/v-myc carrying retrovirus. J Neuroimmunol 27:229-237.

Bornemann KD, Wiederhold KH, Pauli C, Ermini F, Stalder M, Schnell L, Sommer B, Jucker M, Staufenbiel M (2001) Abeta-induced inflammatory processes in microglia cells of APP23 transgenic mice. Am J Pathol 158:63-73.

Bornstein P (1995) Diversity of function is inherent in matricellular proteins: an appraisal of thrombospondin 1. J Cell Biol 130:503-506.

Brockman JA, Scherer DC, McKinsey TA, Hall SM, Qi X, Lee WY, Ballard DW (1995) Coupling of a signal response domain in I kappa B alpha to multiple pathways for NF-kappa B activation. Mol Cell Biol 15:2809-2818.

Brown K, Gerstberger S, Carlson L, Franzoso G, Siebenlist U (1995) Control of I kappa B-alpha proteolysis by site-specific, signal-induced phosphorylation. Science 267:1485-1488.

Burdick D, Soreghan B, Kwon M, Kosmoski J, Knauer M, Henschen A, Yates J, Cotman C, Glabe C (1992) Assembly and aggregation properties of synthetic Alzheimer's A4/beta amyloid peptide analogs. J Biol Chem 267:546-554.

Chen ZJ, Parent L, Maniatis T (1996) Site-specific phosphorylation of IkappaBalpha by a novel ubiquitination-dependent protein kinase activity. Cell 84:853-862.

Combs CK, Johnson DE, Cannady SB, Lehman TM, Landreth GE (1999) Identification of microglial signal transduction pathways mediating a neurotoxic response to amyloidogenic fragments of beta-amyloid and prion proteins. J Neurosci 19:928-939.

Combs CK, Karlo JC, Kao SC, Landreth GE (2001) beta-Amyloid stimulation of microglia and monocytes results in TNFalpha-dependent expres- sion of inducible nitric oxide synthase and neuronal apoptosis. J Neurosci 21:1179-1188.

Cox D, Chang P, Zhang Q, Reddy PG, Bokoch GM, Greenberg S (1997) Requirements for both Racl and Cdc42 in membrane ruffling and phagocytosis in leukocytes. J Exp Med 186:1487-1494.

Dang PM, Stensballe A, Boussetta T, Raad H, Dewas C, Kroviarski Y, Hayem G, Jensen ON, Gougerot-Pocidalo MA, El-Benna J (2006) A specific p47phox -serine phosphorylated by convergent MAPKs mediates neutrophil NADPH oxidase priming at inflammatory sites. J Clin Invest 116:2033-2043

Davalos D, Grutzendler J, Yang G, Kim JV, Zuo Y, Jung S, Littman DR, Dustin ML, Gan WB (2005) ATP mediates rapid microglial response to local brain injury in vivo. Nat Neurosci 8:752-758.

DeLeo FR, Quinn MT (1996) Assembly of the phagocyte NADPH oxidase: molecular interaction of oxidase proteins. J Leukoc Biol 60:677-691.

El Bekay R, Alba G, Reyes ME, Chacón P, Vega A, Martín-Nieto J, Jiménez J, Ramos E, Oliván J, Pintado E, Sobrino F (2007) Rac2 GTPase activation by angiotensin II is modulated by $\mathrm{Ca} 2+/$ calcineurin and mitogenactivated protein kinases in human neutrophils. J Mol Endocrinol 39:351-363.

El Benna J, Faust RP, Johnson JL, Babior BM (1996) Phosphorylation of the respiratory burst oxidase subunit $\mathrm{p} 47 \mathrm{phox}$ as determined by twodimensional phosphopeptide mapping. Phosphorylation by protein kinase $\mathrm{C}$, protein kinase $\mathrm{A}$, and a mitogen-activated protein kinase. J Biol Chem 271:6374-6378.

English BK, Ihle JN, Myracle A, Yi T (1993) Hck tyrosine kinase activity modulates tumor necrosis factor production by murine macrophages. J Exp Med 178:1017-1022.

Fassbender K, Walter S, Kühl S, Landmann R, Ishii K, Bertsch T, Stalder AK, Muehlhauser F, Liu Y, Ulmer AJ, Rivest S, Lentschat A, Gulbins E, Jucker M, Staufenbiel M, Brechtel K, Walter J, Multhaup G, Penke B, Adachi Y, et al. (2004) The LPS receptor (CD14) links innate immunity with Alzheimer's disease. FASEB J 18:203-205.

Ferrer I (2004) Stress kinases involved in tau phosphorylation in Alzheimer's disease, tauopathies and APP transgenic mice. Neurotox Res 6:469-475.

Finco TS, Beg AA, Baldwin AS Jr (1994) Inducible phosphorylation of I kappa $B$ alpha is not sufficient for its dissociation from NF-kappa $B$ and is inhibited by protease inhibitors. Proc Natl Acad Sci USA 91:11884-11888.

Flanary BE, Sammons NW, Nguyen C, Walker D, Streit WJ (2007) Evidence that aging and amyloid promote microglial cell senescence. Rejuvenation Res 10:61-74.

Floden AM, Combs CK (2006) Beta-amyloid stimulates murine postnatal and adult microglia cultures in a unique manner. J Neurosci 26:4644-4648.

Gangloff SC, Hijiya N, Haziot A, Goyert SM (1999) Lipopolysaccharide structure influences the macrophage response via CD14-independent and CD14-dependent pathways. Clin Infect Dis 28:491-496.

Geng Y, Gulbins E, Altman A, Lotz M (1994) Monocyte deactivation by interleukin 10 via inhibition of tyrosine kinase activity and the Ras signaling pathway. Proc Natl Acad Sci U S A 91:8602-8606.

Giovannini MG, Scali C, Prosperi C, Bellucci A, Vannucchi MG, Rosi S, Pepeu G, Casamenti F (2002) Beta-amyloid-induced inflammation and cholinergic hypofunction in the rat brain in vivo: involvement of the p38MAPK pathway. Neurobiol Dis 11:257-274.

Gregory CD, Devitt A (1999) CD14 and apoptosis. Apoptosis 4:11-20.

Heine H, Kirschning CJ, Lien E, Monks BG, Rothe M, Golenbock DT (1999) Cutting edge: cells that carry A null allele for toll-like receptor 2 are capable of responding to endotoxin. J Immunol 162:6971-6975.

Heinzelmann M, Polk HC Jr, Miller FN (1998) Modulation of lipopolysaccharideinduced monocyte activation by heparin-binding protein and fucoidan. Infect Immun 66:5842-5847.

Hensley K, Floyd RA, Zheng NY, Nael R, Robinson KA, Nguyen X, Pye QN, Stewart CA, Geddes J, Markesbery WR, Patel E, Johnson GV, Bing G (1999) p38 kinase is activated in the Alzheimer's disease brain. J Neurochem 72:2053-2058.

Ishibashi Y, Claus S, Relman DA (1994) Bordetella pertussis filamentous hemagglutinin interacts with a leukocyte signal transduction complex and stimulates bacterial adherence to monocyte CR3 (CD11b/CD18). J Exp Med 180:1225-1233.

Itagaki S, McGeer PL, Akiyama H, Zhu S, Selkoe D (1989) Relationship of 
microglia and astrocytes to amyloid deposits of Alzheimer disease. J Neuroimmunol 24:173-182.

Jana M, Palencia CA, Pahan K (2008) Fibrillar amyloid-beta peptides activate microglia via TLR2: implications for Alzheimer's disease. J Immunol 181:7254-7262.

Jin Y, Yan EZ, Fan Y, Zong ZH, Qi ZM, Li Z (2005) Sodium ferulate prevents amyloid-beta-induced neurotoxicity through suppression of p38 MAPK and upregulation of ERK-1/2 and Akt/protein kinase B in rat hippocampus. Acta Pharmacol Sin 26:943-951.

Kielian T (2006) Toll-like receptors in central nervous system glial inflammation and homeostasis. J Neurosci Res 83:711-730.

Kim SH, Smith CJ, Van Eldik LJ (2004) Importance of MAPK pathways for microglial pro-inflammatory cytokine IL-1 beta production. Neurobiol Aging 25:431-439.

Kim WS, Ordija CM, Freeman MW (2003) Activation of signaling pathways by putative scavenger receptor class A (SR-A) ligands requires CD14 but not SR-A. Biochem Biophys Res Commun 310:542-549.

Koenigsknecht J, Landreth G (2004) Microglial phagocytosis of fibrillar $\beta$-amyloid through a $\beta_{1}$ integrin-dependent mechanism. J Neurosci 24:9838-9846.

Kong L, Ge BX (2008) MyD88-independent activation of a novel actinCdc42/Rac pathway is required for Toll-like receptor-stimulated phagocytosis. Cell Res 18:745-755.

Kopec KK, Carroll RT (1998) Alzheimer's beta-amyloid peptide 1-42 induces a phagocytic response in murine microglia. J Neurochem 71:2123-2131.

Laroux FS, Romero X, Wetzler L, Engel P, Terhorst C (2005) Cutting edge: MyD88 controls phagocyte NADPH oxidase function and killing of gram-negative bacteria. J Immunol 175:5596-5600.

Lee DJ, Cox D, Li J, Greenberg S (2000) Rac1 and Cdc42 are required for phagocytosis, but not NF-kappaB-dependent gene expression, in macrophages challenged with Pseudomonas aeruginosa. J Biol Chem 275:141-146.

Letiembre M, Liu Y, Walter S, Hao W, Pfander T, Wrede A, Schulz-Schaeffer W, Fassbender K (2009) Screening of innate immune receptors in neurodegenerative diseases: a similar pattern. Neurobiol Aging 30:759-768.

Liu Y, Walter S, Stagi M, Cherny D, Letiembre M, Schulz-Schaeffer W, Heine H, Penke B, Neumann H, Fassbender K (2005) LPS receptor (CD14): a receptor for phagocytosis of Alzheimer's amyloid peptide. Brain 128:1778-1789.

Lorenzo A, Yankner BA (1994) Beta-amyloid neurotoxicity requires fibril formation and is inhibited by congo red. Proc Natl Acad Sci U S A 91:12243-12247.

Mandrekar S, Jiang Q, Lee CY, Koenigsknecht-Talboo J, Holtzman DM, Landreth GE (2009) Microglia mediate the clearance of soluble A $\beta$ through fluid phase macropinocytosis. J Neurosci 29:4252-4262.

McDonald DR, Brunden KR, Landreth GE (1997) Amyloid fibrils activate tyrosine kinase-dependent signaling and superoxide production in microglia. J Neurosci 17:2284-2294.

McDonald DR, Bamberger ME, Combs CK, Landreth GE (1998) $\beta$-Amyloid fibrils activate parallel mitogen-activated protein kinase pathways in microglia and THP1 monocytes. J Neurosci 18:4451-4460.

Meda L, Bonaiuto C, Baron P, Otvos L Jr, Rossi F, Cassatella MA (1996) Priming of monocyte respiratory burst by beta-amyloid fragment (2535). Neurosci Lett 219:91-94.

Medzhitov R (2001) Toll-like receptors and innate immunity. Nat Rev Immunol 1:135-145.

Minoretti P, Gazzaruso C, Vito CD, Emanuele E, Bianchi M, Coen E, Reino M, Geroldi D (2006) Effect of the functional toll-like receptor 4 Asp299Gly polymorphism on susceptibility to late-onset Alzheimer's disease. Neurosci Lett 391:147-149.

Neal MD, Leaphart C, Levy R, Prince J, Billiar TR, Watkins S, Li J, Cetin S, Ford H, Schreiber A, Hackam DJ (2006) Enterocyte TLR4 mediates phagocytosis and translocation of bacteria across the intestinal barrier. J Immunol 176:3070-3079.

Nimmerjahn A, Kirchhoff F, Helmchen F (2005) Resting microglial cells are highly dynamic surveillants of brain parenchyma in vivo. Science 308:1314-1318.

Osada Y, Sunatani T, Kim IS, Nakanishi Y, Shiratsuchi A (2009) Signalling pathway involving GULP, MAPK, and Rac1 for SR-BI-induced phagocytosis of apoptotic cells. J Biochem 145:387-394.

Park JY, Kim HY, Jou I, Park SM (2008) GM1 induces p38 and microtubule dependent ramification of rat primary microglia in vitro. Brain Res 1244:13-23.

Perlmutter LS, Barron E, Chui HC (1990) Morphologic association between microglia and senile plaque amyloid in Alzheimer's disease. Neurosci Lett 119:32-36.

Pfeiffer A, Böttcher A, Orsó E, Kapinsky M, Nagy P, Bodnár A, Spreitzer I, Liebisch G, Drobnik W, Gempel K, Horn M, Holmer S, Hartung T, Multhoff G, Schütz G, Schindler H, Ulmer AJ, Heine H, Stelter F, Schütt C, et al. (2001) Lipopolysaccharide and ceramide docking to CD14 provokes ligand-specific receptor clustering in rafts. Eur J Immunol 31:3153-3164.

Pick E (1986) Microassays for superoxide and hydrogen peroxide production and nitroblue tetrazolium reduction using an enzyme immunoassay microplate reader. Methods Enzymol 132:407-421.

Pyo H, Jou I, Jung S, Hong S, Joe EH (1998) Mitogen-activated protein kinases activated by lipopolysaccharide and beta-amyloid in cultured rat microglia. Neuroreport 9:871-874.

Qin L, Li G, Qian X, Liu Y, Wu X, Liu B, Hong JS, Block ML (2005) Interactive role of the toll-like receptor 4 and reactive oxygen species in LPSinduced microglia activation. Glia 52:78-84.

Richard KL, Filali M, Préfontaine P, Rivest S (2008) Toll-like receptor 2 acts as a natural innate immune receptor to clear amyloid $\beta_{1-42}$ and delay the cognitive decline in a mouse model of Alzheimer's disease. J Neurosci 28:5784-5793.

Ridley AJ, Paterson HF, Johnston CL, Diekmann D, Hall A (1992) The small GTP-binding protein rac regulates growth factor-induced membrane ruffling. Cell 70:401-410.

Sánchez-Mejorada G, Rosales C (1998) Signal transduction by immunoglobulin Fc receptors. J Leukoc Biol 63:521-533.

Sanlioglu S, Williams CM, Samavati L, Butler NS, Wang G, McCray PB Jr, Ritchie TC, Hunninghake GW, Zandi E, Engelhardt JF (2001) Lipopolysaccharide induces Rac1-dependent reactive oxygen species formation and coordinates tumor necrosis factor-alpha secretion through IKK regulation of NF-kappa B. J Biol Chem 276:30188-30198.

Saura J, Tusell JM, Serratosa J (2003) High-yield isolation of murine microglia by mild trypsinization. Glia 44:183-189.

Savage MJ, Lin YG, Ciallella JR, Flood DG, Scott RW (2002) Activation of c-Jun N-terminal kinase and p38 in an Alzheimer's disease model is associated with amyloid deposition. J Neurosci 22:3376-3385.

Scholtzova H, Kascsak RJ, Bates KA, Boutajangout A, Kerr DJ, Meeker HC, Mehta PD, Spinner DS, Wisniewski T (2009) Induction of toll-like receptor 9 signaling as a method for ameliorating Alzheimer's diseaserelated pathology. J Neurosci 29:1846-1854.

Selkoe DJ (2000) Toward a comprehensive theory for Alzheimer's disease. Hypothesis: Alzheimer's disease is caused by the cerebral accumulation and cytotoxicity of amyloid beta-protein. Ann N Y Acad Sci 924:17-25.

Sendide K, Reiner NE, Lee JS, Bourgoin S, Talal A, Hmama Z (2005) Crosstalk between CD14 and complement receptor 3 promotes phagocytosis of mycobacteria: regulation by phosphatidylinositol 3-kinase and cytohesin-1. J Immunol 174:4210-4219.

Sierra A, Gottfried-Blackmore AC, McEwen BS, Bulloch K (2007) Microglia derived from aging mice exhibit an altered inflammatory profile. Glia 55:412-424.

Smits HA, de Vos NM, Wat JW, van der Bruggen T, Verhoef J, Nottet HS (2001) Intracellular pathways involved in TNF-alpha and superoxide anion release by Abeta(1-42)-stimulated primary human macrophages. J Neuroimmunol 115:144-151.

Stefanová I, Corcoran ML, Horak EM, Wahl LM, Bolen JB, Horak ID (1993) Lipopolysaccharide induces activation of CD14-associated protein tyrosine kinase p53/56lyn. J Biol Chem 268:20725-20728.

Streit WJ, Mrak RE, Griffin WS (2004) Microglia and neuroinflammation: a pathological perspective. J Neuroinflammation 1:14.

Sumimoto H, Hata K, Mizuki K, Ito T, Kage Y, Sakaki Y, Fukumaki Y, Nakamura M, Takeshige K (1996) Assembly and activation of the phagocyte NADPH oxidase. Specific interaction of the N-terminal Src homology 3 domain of p47phox with p22phox is required for activation of the NADPH oxidase. J Biol Chem 271:22152-22158.

Sun A, Liu M, Nguyen XV, Bing G (2003) P38 MAP kinase is activated at early stages in Alzheimer's disease brain. Exp Neurol 183:394-405.

Taborda CP, Casadevall A (2002) CR3 (CD11b/CD18) and CR4 (CD11c/ CD18) are involved in complement-independent antibody-mediated phagocytosis of Cryptococcus neoformans. Immunity 16:791-802. 
Tahara K, Kim HD, Jin JJ, Maxwell JA, Li L, Fukuchi K (2006) Role of toll-like receptor signalling in Abeta uptake and clearance. Brain 129:3006-3019.

Tang G, Yue Z, Talloczy Z, Hagemann T, Cho W, Messing A, Sulzer DL, Goldman JE (2008) Autophagy induced by Alexander disease-mutant GFAP accumulation is regulated by p38/MAPK and mTOR signaling pathways. Hum Mol Genet 17:1540-1555.

Traenckner EB, Pahl HL, Henkel T, Schmidt KN, Wilk S, Baeuerle PA (1995) Phosphorylation of human I kappa B-alpha on serines 32 and 36 controls I kappa B-alpha proteolysis and NF-kappa B activation in response to diverse stimuli. EMBO J 14:2876-2883.

Triantafilou M, Brandenburg K, Kusumoto S, Fukase K, Mackie A, Seydel U, Triantafilou K (2004) Combinational clustering of receptors following stimulation by bacterial products determines lipopolysaccharide responses. Biochem J 381:527-536.

Triantafilou M, Gamper FG, Haston RM, Mouratis MA, Morath S, Hartung T, Triantafilou K (2006) Membrane sorting of toll-like receptor (TLR)2/6 and TLR2/1 heterodimers at the cell surface determines heterotypic associations with CD36 and intracellular targeting. J Biol Chem 281:31002-31011.

Udan ML, Ajit D, Crouse NR, Nichols MR (2008) Toll-like receptors 2 and 4 mediate $\mathrm{Abeta}(1-42)$ activation of the innate immune response in a human monocytic cell line. J Neurochem 104:524-533.

Underhill DM, Ozinsky A, Hajjar AM, Stevens A, Wilson CB, Bassetti M, Aderem A (1999) The Toll-like receptor 2 is recruited to macrophage phagosomes and discriminates between pathogens. Nature 401:811-815.

Van Muiswinkel FL, Raupp SF, de Vos NM, Smits HA, Verhoef J, Eikelenboom P, Nottet HS (1999) The amino-terminus of the amyloid-beta protein is critical for the cellular binding and consequent activation of the respiratory burst of human macrophages. J Neuroimmunol 96:121-130. van Oosten M, van Amersfoort ES, van Berkel TJ, Kuiper J (2001) Scavenger receptor-like receptors for the binding of lipopolysaccharide and lipoteichoic acid to liver endothelial and Kupffer cells. J Endotoxin Res 7:381-384

Walter S, Letiembre M, Liu Y, Heine H, Penke B, Hao W, Bode B, Manietta N, Walter J, Schulz-Schuffer W, Fassbender K (2007) Role of the toll-like receptor 4 in neuroinflammation in Alzheimer's disease. Cell Physiol Biochem 20:947-956.

Wilkinson B, Koenigsknecht-Talboo J, Grommes C, Lee CY, Landreth G (2006) Fibrillar beta-amyloid-stimulated intracellular signaling cascades require $\mathrm{Vav}$ for induction of respiratory burst and phagocytosis in monocytes and microglia. J Biol Chem 281:20842-20850.

Wong WS, Simon DI, Rosoff PM, Rao NK, Chapman HA (1996) Mechanisms of pertussis toxin-induced myelomonocytic cell adhesion: role of Mac-1(CD11b/CD18) and urokinase receptor (CD87). Immunology 88:90-97.

Yamamori T, Inanami O, Nagahata H, Cui Y, Kuwabara M (2000) Roles of p38 MAPK, PKC and PI3-K in the signaling pathways of NADPH oxidase activation and phagocytosis in bovine polymorphonuclear leukocytes. FEBS Lett 467:253-258.

Yan SR, Al-Hertani W, Byers D, Bortolussi R (2002) Lipopolysaccharidebinding protein- and CD14-dependent activation of mitogen-activated protein kinase p38 by lipopolysaccharide in human neutrophils is associated with priming of respiratory burst. Infect Immun 70:4068-4074.

Zhu X, Rottkamp CA, Boux H, Takeda A, Perry G, Smith MA (2000) Activation of p38 kinase links tau phosphorylation, oxidative stress, and cell cycle-related events in Alzheimer disease. J Neuropathol Exp Neurol 59:880-888.

Zuluaga S, Gutiérrez-Uzquiza A, Bragado P, Alvarez-Barrientos A, Benito M Nebreda AR, Porras A (2007) p38alpha MAPK can positively or negatively regulate Rac-1 activity depending on the presence of serum. FEBS Lett 581:3819-3825. 